Catholic Norman Vincent Peales would be saying similar things in a scenario involving the presidency of many Catholic colleges?

Issue \#2: Let us mention one other problematic situation regarding de facto prejudicial practices. Not long ago, TOIL, the teaching opportunities information listing published by the Council on the Study of Religion contained an ad for a moral theologian. The ad mentioned the various qualities desired, pointed out that the institution was an affirmative action-equal opportunity employer, and concluded: "Position envisions a Roman Catholic priest or unordained layperson." This curious phrase "unordained layperson" clearly conveys the message that no former Catholic clerics will be considered by this "equal opportunity employer." The point of this example is not to attack the institution involved, which has at least been clear in its prejudicially exclusionary policy, but to illustrate a continuing problem in many places. Less admirable than this particular institution are those who would smirk at the curious phraseology of the ad but covertly follow the same policy.

So let us by all means not neglect attending to those remaining pockets of anti-Catholic prejudice and those gaps of consciousness that are equivalently the same, but let us also be sensitized anew to possibly prejudicial gaps of consciousness within Catholicism such as those we have mentioned. The above examples are shared in the spirit of reflecting on Chapter III of the 1971 Synod document, "Justice in the World," which holds that everyone who ventures to speak to people about justice must be careful to be just. Similarly those who venture to speak of prejudice must be careful to avoid prejudice. As Catholics and others enter into matters dealing with justice and prejudice may it be done with a self-scrutiny that will be enriching to all.

-RODGER VAN ALLEN

\title{
WEAR COMFORTABLE CLOTHES, BRING BROWN PAPER BAG
}

Mysticism has come to suburbia. The event might well have passed without notice, had the New York Times not begun a Sunday supplement covering Westchester.

“Modern Mysticism," panel discussion today at 4 P.M. to 6. $\$ 7.50$, students $\$ 5$, with dinner and discussion afterward $\$ 15$. Workshop, Wednesday at 10 A.M. to 2 P.M. \$10. Wear comfortable clothes, bring brown paper bag that will fit over your head. Center for Human Potential, Fawn Ridge.

"Total Environments: Mystical Adornments for the Body,"' by Alex and Lee. The Gallery, Green Glades. 
As good residents of this restful and woodsy enclave north of the great metropolis, we thought we ought to look into this new form of the fashionable pursuit of leisure, and found ourselves interviewing Dr. Ananda T. Burbank, Professor of Comparative Mysticism at the Upper Nyack Ladies' Academy, and guiding spirit behind the workshops and panels.

"Ah, yes," said Professor Burbank, "no doubt it sounds a bit silly to you. But did you know that when Joan of Arc, as a girl of twelve, was first troubled by voices-voices not of an inspirational kind, you understand, but just worrisome, prankish spirits telling her that she was wanted at home when she wasn't, and that sort of thing-she finally sought respite by covering her head with a brown paper bag. It was then that she first heard the robust voice of St. Michael, telling her that she was to deliver France from its English masters. Concealed within her suit of armor she always carried a brown paper bag, and put it over her head whenever she wished to speak with Saints Margaret and Catherine. That was why she ceased to hear her voices during the trial. The British had taken away her suit of mail, and obliged her to wear more feminine attire. Inadvertently, they took away her brown paper bag as well."

We confessed that although we had read the Michelet and Sachville-West biographies, we could not recall having read that.

"Of course you didn't read it!" he exclaimed, trying to be as patient with us as he could. "It was deleted from the records of the trial by the Church!"

"Because the Church-" we ventured; "- -because the Church didn't want people getting ideas!" he chortled.

"I suppose you have heard Meister Eckhart's famous dictum, "The eye with which I see God is the eye with which God sees me'? What do you suppose was the occasion for that bit of wisdom? What do you suppose the old boy was doing when he said that?"

"Was he sitting in his study with his head in a brown paper bag?" we gamely suggested.

"Of course!" said Ananda T. Burbank, tossing back his great shock of silvery hair. "And you have heard of Martin Luther's revelation in the tower?"

We mumbled something about Erik Erikson.

"That Erikson chap has it all wrong, of course. These Freudians. Always on the lookout for something unpleasant. They overlook the simple facts, and make matters preposterously complicated."

We could see he was off on a tangent, and thought to bring him back by asking for his theory of the tower incident.

"It's quite simple. The little room Luther refers to (sometimes rather cryptically as the "Cl.') was simply the monastic broom closet at Erfurt."

"Where the brown paper bags were kept?" we offered. 
"Ah, you are a bright fellow," Ananda T. Burbank beamed. "You see how simple it all is? Young Luther was obsessed, as we all know, by his unworthiness in the sight of God. One day, after sweeping out the chapter room, he went to the tower closet to hang up his dust brush and pan, and was overcome by an attack of unworthiness. He spotted the stack of neatly folded brown paper bags, quickly took hold of one, and popped it over his head. He lost sight of the world of works, and caught sight of the world of faith alone. Needless to say, it was quite a revelation. From that day forward he made it a practice to carry a paper bag tucked away in his cassock. Some months later, the old anxiety returned when he was with his fellow monks in the choir, and on went the brown paper bag. Young Luther breathed a sigh of relief.

"There was a good deal of buzzing about amongst the younger chaps, as you can well imagine, and not a little tittering. Old Staupitz looked over to see what was doing, and called out: 'Is that you under that brown paper bag, Father Martin?' ",

"Luther's muffled reply was hardly audible, though one eyewitness later insisted he had heard Luther say 'Non sum,' while another swore he said 'Ich bin's nit.' What was not reported was Luther's exultant remark when he removed the bag: 'I am out of the womb! I am free of Mother Church!' Ah, no, no one wanted to report that one. But now the secret is-ahem-"

"Out of the bag," we said obligingly.

"Quite so," Professor Burbank observed with satisfaction.

Professor Burbank is currently at work on a book whose working title is The New Doors of Perception. It is to be the first full-length account of P.B.T. (Paper Bag Therapy).

"My publisher wants to call it It's In the Bag. I fear they are incapable of the proper measure of seriousness. Worst of all, I fear having it become another shallow fad. There are no shortcuts to genuine mysticism," Dr. Burbank warned.

"I myself spent years of preparation, and was familiar with all the classics of mystical literature, before I tried on my first brown paper bag. But you know how it is today. The culture of youth. Everybody in a hurry. Speedy planes, speedy cars, speed-reading.

"P.B.T. is not instant mysticism. It can only serve as a catalyst to those who are spiritually ready for deeper levels of awareness."

We pondered these wise words on our way home, and nearly forgot to pick up the meat and groceries at Gristede's.

"Do you want that in a box or a bag?" old Fred asked us from behind the counter.

"In a bag," we replied. 


\section{NOTRE OAME FALL 1978}

\section{THE CITY OF THE GODS:}

A Study in Myth and Mortality

John S. Dunne. Shows how man's political and social mythologies from ancient Sumeria to the present reflect diverse responses to the inevitability of death.

$\$ 12.95 \mathrm{cl} ., \$ 4.95 \mathrm{pa}$.

\section{THE WAY OF ALL THE EARTH:}

\section{Experiments in Truth and Religion}

John S. Dunne. Reflections on the common experiences of man, as revealed in the writings of the Hindu-Buddhist, Islamic, and Christian traditions.

$\$ 12.95 \mathrm{cl}$., \$3.95 pa.

\section{CATHOLIC REVIVALISM:}

The American Experience, 1830-1900

Jay P. Dolan. "... This is a remarkable study, casting new light on the shape of Catholicism in 19th-century America, illuminating from an unexpected angle discussion of the 'Americanization' of Catholicism, and filling in the story of revivalism." - Christian Century.

\section{TRUTHFULNESS AND TRAGEDY:}

\section{Further Investigations in Christian Ethics}

Stanley Hauerwas. ". . . A further offering of ethical wisdom and insight from Stanley Hauerwas . . . one of the most consistently rewarding guides to a wide range of ethical problems. ... ."Commonweal.

Available in November

\section{ETHICS AND PROBLEMS OF THE 21ST CENTURY}

Kenneth Goodpaster and Kenneth Sayre, eds. Examines the ethical considerations underlying problems of increasing consequence for the 21st century, including world hunger, environmentalism, and landmark preservation.

\section{UNIVERSITY OF NOTRE DAME PRESS} Notre Dame, Indiana 46556 